Artigo

\title{
Calibration of Ångström-Prescott Equation to Estimate Daily Solar Radiation on Rio Grande do Norte State, Brazil
}

\author{
Felipe J. de Medeiros ${ }^{1}$, Claudio M. Santos e Silva ${ }^{1,2}$, Bergson G. Bezerra ${ }^{1,2}$ \\ ${ }^{1}$ Departamento de Ciências Atmosféricas e Climáticas, Universidade Federal \\ do Rio Grande do Norte, Natal, RN, Brazil. \\ ${ }^{2}$ Programa de Pós-graduação em Ciências Climáticas, Universidade Federal \\ do Rio Grande do Norte, Natal, RN, Brazil.
}

Received in January 16, 2016 - Accepted in June 14, 2017

\begin{abstract}
Knowledge of solar radiation is required for many applications. However, this atmospheric variable is not measured with an adequate space resolution. In this sense, to sites where solar radiation data are not directly measure, estimative using Ångström-Prescott equation can be used in order to provide solar radiation data, with input of sunshine duration. Thus, the objective of present study was to calibrate the Ångström-Prescott equation for different sites in Rio Grande do Norte state, Brazil. The performance of the calibrated Ångström-Prescott equation was evaluated by comparing of daily global solar radiation observed in situ. The MBE (Mean Bias Error) was lower than $1.50 \mathrm{MJ} \mathrm{m}^{-2}$ day $^{-1}$, the Pearson's correlation coefficient about 0.90 and Willmott's index of agreement higher than 0.90 , which are considered satisfactory.
\end{abstract}

Keywords: semiarid region; sunshine duration; Ångström-Prescott equation.

\section{Calibração da Equação de Ångström-Prescott para Estimar a Radiação Solar Diária no Estado do Rio Grande do Norte, Brasil}

\begin{abstract}
Resumo
Conhecimento da radiação solar é necessária para muitas aplicações. No entanto, esta variável atmosférica não é medida com uma resolução espacial adequada. Neste sentido, nos locais onde os dados da radiação solar não são medidos diretamente, a equação de Ångström-Prescott pode ser usada a fim de fornecer dados de radiação solar, com base na insolação. Assim, o objetivo do presente estudo foi calibrar a equação de Ångström-Prescott para diferentes locais no Rio Grande do Norte, Brasil. O desempenho da equação Ångström-Prescott calibrada foi avaliada através da comparação da radiação solar global diária observada in situ. O MBE foi menor que $1,50 \mathrm{MJ} \mathrm{m}^{-2} \mathrm{dia}^{-1}$, o coeficiente de correlação de Pearson cerca de 0,90 e índice de concordância de Willmott foi superior a 0,90, que são considerados satisfatórios.
\end{abstract}

Palavras-chave: região semiárida, insolação, equação Ångström-Prescott.

\section{Introduction}

Knowledge of solar radiation on the Earth's surface is required for many applications including architecture, active and passive solar energy systems, agriculture, meteorology and climatology. This variable is a proxy evaluating the availability of solar resources, being a prerequisite at any desired site (Sen et al., 2001; Morandi, 2009). However, solar radiation is not directly measured with adequate space resolution and time sampling due to cost of mainte- nance and the frequent calibration procedures (Santos et $a l ., 2014)$. Therefore these data are usually scarce, but to the places where solar radiation data are not available, this meteorological variable can be estimated from measurements of daily sunshine duration, which has locations with long-term records, applied to equation proposed by Ångström-Prescott (Ångström, 1924; Prescott, 1940).

The Ångström-Prescott equation was proposed by Ångström (1924) and adapted by Prescott (1940). Originally, Ångström (1924) proposed a linear relationship be-

Autor de correspondência: Bergson G. Bezerra, bergson.bezerra@gmail.com. 
tween the ratio of average daily global radiation and the corresponding value. The model was development under conditions of clear sky day and the ratio of average daily sunshine duration to the maximum possible sunshine duration. However, the original equation needs of clear sky radiation data. Thus, Prescott (1940) suggested the use of extraterrestrial radiation $\left(H_{0}\right)$ to replace it, and this modification led to the formation of the Ångström-Prescott equation (Liu et al., 2009).

From these Prescott modifications, the ÅngströmPrescott equation can be used with daily data, fortnightly, monthly, seasonal, and annual. The $a$ and $b$ coefficients should be adjusted locally and for different times of the year, in order to better represent the depending on the variation of solar radiation brightness (Carvalho et al., 2011; Allen et al., 1998). The coefficient $a$ quantifies physically the fraction of diffuse radiation to $H_{0}$, and $b$ the fraction of direct radiation to $H_{0}$ (Hinrichsen, 1994).

The coefficients $a$ and $b$ of Ångström-Prescott equation has dependency on physical characteristics of the atmospheric layer and are influenced by local latitude and altitude, in addition, depends on seasonal variability of the atmospheric variable (rainfall, wind, humidity, and aerosol concentrations). The aerosols influence the visible light most efficient (Meesang et al., 2013). On regions near to coast the sea-salt is an important scattering of the solar radiation, affecting the atmospheric radiative balance (Meesang et al., 2013), for example, the sea-salt interacting with incoming solar radiation and the outgoing terrestrial radiation. In another hand, hydrophobic soil dust aerosol, the sea-salt particles uptake water readily and hence, are highly scattered at shortwave wavelengths with virtually no absorption (Takemura et al., 2002; Meesang et al., 2013). This interaction between sea-salt and solar radiation can indicate substantial changes in the coefficients $a$ and $b$ of Ångström-Prescott equation, especially in Natal and Macau sites, that are affect by the ocean.

The report 56 (Irrigation and Drainage Paper) of Food and Agriculture Organization (FAO) (Allen et al., 1998) recommends values, respectively, of 0.25 and 0.50 to coefficients $a$ and $b$ of Ångström-Prescott equation. However, values of the coefficients $a$ and $b$ has been ranged from 0.19 to 0.40 and from 0.43 to 0.61 , respectively, in different regions around the world (Iziomon and Mayer, 2002; Dornelas et al., 2006; Rahime et al., 2012; Belúcio et al., 2014). For this reason, Allen et al. (1998) indicate the need of local calibration in order to improve the referred equation, since both $a$ and $b$ are depending on atmospheric conditions (humidity, rain occurrence) and solar declination, which varies with the latitude and month.

The calibration and application of Ångström-Prescott equation has been performed in numerous regions of the world (Almorox et al., 2005, Liu et al., 2009; Rahimi et al., 2012; Khorasanizadeh and Mohammadi, 2013), including tropical zones (Belúcio et al., 2014; Okundamiya et al.,
2016). The results obtained in these studies shown a satisfactory performance of the calibrated Angström-Prescott equation relatively to observations. The use of your calibration is an useful way to estimate daily solar radiation from daily sunshine duration data to the weather station where has not records of the solar radiation, given that there are a time series of daily sunshine duration over forty years.

In this context, the objective of the present paper is to calibrate the equation of Ångström-Prescott considering the seasonal time scale, in addition a calibration for full period (referred to as annual hereafter) of four meteorological stations (Natal, Apodi, Macau, and Caicó) was performed. The sites are located within Rio Grande do Norte state, Northeast region of Brazil. After calibration, the performance of the models was evaluated by comparing the values of daily global solar irradiance estimated by using calibrated models with observed data in the four weather automatic stations. The determination of the coefficients of Angström-Prescott equation is necessary given that the weather stations there are a long-term series of sunshine duration data. Thus, Ångström-Prescott equation locally calibrated can provide reliable estimative of daily solar radiation for climatological and renewable energy studies.

\section{Material and Methods}

The study uses daily solar radiation data and daily sunshine duration measured simultaneously on four weather stations on Rio Grande do Norte State namely Natal, Macau, Apodi, and Caicó (Fig. 1), during 2008-2013 period. The weather stations coordinates was well as the climate classification according to Thornthwaite (1948) are presented in Table 1.

The Rio Grande do Norte (RN) state is located on Northeastern region of Brazil (Fig. 1). More than $90 \%$ of the land surface area is classified as Semi-Arid and only the eastern coastline has a humid climate. Due to its location, north coast of Northeastern region and near the equator, between latitudes $4^{\circ} 49^{\prime} \mathrm{S}$ and $7^{\circ} 10^{\prime} \mathrm{S}$, in RN the sunshine duration is about 2,800 hours per year (INMET, 1992).

Measurements of daily sunshine duration data $(n)$ were obtained with a Campbell-Stokes heliograph, while daily solar radiation data were obtained by using thermopile type pyranometers model SP Lite2 (Kipp \& Zonen, Delft, the Netherland). The daily solar radiation was sampled every 5 seconds, integrated and stored hourly values.

The coefficients of Ångström-Prescott equation (Eq. (1)) i.e. $a$ and $b$ (intercept and slope, respectively) were determined through linear regression analysis by using the ordinary least squares method relating daily ratio values $H / H_{0}$ (dependent variable) $v s$. the daily values of $n / N$ ratio (independent variable) (Wilks, 2006). The $a$ and $b$ values were obtained from data grouped by season, namely: summer (December-January-February, DJF), autumn (MarchApril-May, MAM), winter (June-July-August, JJA) and spring (September-October-November, SON), finally to 


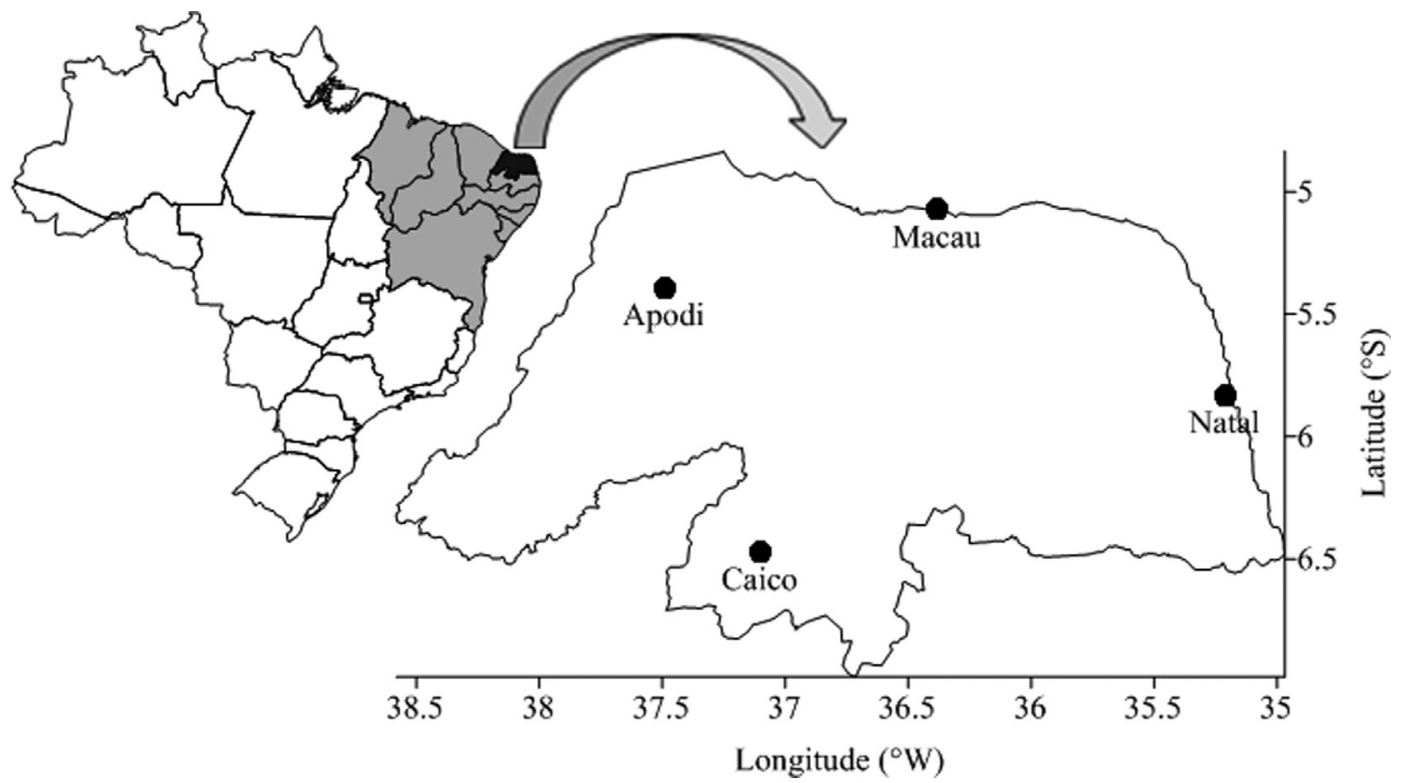

Figure 1 - Map of Brazil (left figure) in which is highlighted Northeast region (clay) and Rio Grande do Norte state (black) for which the location of the four weather stations is shown on the greatest figure.

Table 1 - Geographical coordinates and annual climatological values of air temperature (Air Temp.), Precipitation (Prec.), relative humidity (Rel. Hum.), and sunshine duration, beyond climate type of weather stations used in this study.

\begin{tabular}{lcccccccc}
\hline Weather Station & Lat. $\left({ }^{\circ} \mathrm{S}\right)$ & Lon. $\left({ }^{\circ} \mathrm{W}\right)$ & Elev. $(\mathrm{m})$ & Air Temp. $\left({ }^{\circ} \mathrm{C}\right)$ & Prec. $(\mathrm{mm})$ & Rel. Hum. $(\%)$ & Sunshine $(\mathrm{h})$ & Climate \\
\hline Natal & 5.92 & 32.50 & 48.6 & 26.0 & 1465 & 77.3 & 2968.0 & Humid \\
Macau & 5.12 & 36.77 & 32.0 & 26.8 & 507 & 70.8 & 2686.0 & Semi-Arid \\
Apodi & 5.62 & 37.82 & 150.0 & 27.1 & 893 & 66.8 & 3041.1 & Semi-Arid \\
Caicó & 6.47 & 37.68 & 169.2 & 26.1 & 648 & 63.2 & 2700.0 & Semi-Arid \\
\hline
\end{tabular}

coefficient were calculated for the entire data (annual calibration):

$$
H / H_{0}=\left[a+b\left(\frac{n}{N}\right)\right]
$$

where $H_{0}$ is daily extraterrestrial radiation $\left(\mathrm{MJ} \mathrm{m}^{-2}\right.$ day $\left.^{-1}\right)$ (Eq. (2)), $N$ is daily maximum sunshine duration (Eq. (3)).

The daily extraterrestrial radiation was calculated according Iqbal (1983) following the equation:

$$
H_{0}=\frac{1440 \cdot E_{0} \cdot G_{S C}}{\pi}(\omega \cdot \sin \varphi \cdot \sin \delta+\cos \varphi \cdot \cos \delta \cdot \sin \omega)(2
$$

where $E_{0}$ the eccentricity correction factor of the Earth's orbit, calculated as suggested by Spencer (1971) (Eq. (4)), $G_{S C}$ is the solar constant $\left(0.082 \mathrm{MJ} \mathrm{m}^{-2} \mathrm{~min}^{-1}\right), \omega$ is the hourly angle (Eq. (6)), $\varphi$ is local latitude, and $\delta$ is solar declination which was calculated follows Spencer (1971) (Eq. (7)).

$$
N=\frac{2 \omega}{15}
$$

$$
\begin{aligned}
& E_{0}=1.000110+0.034221 \cos \Gamma+0.001280 \sin \Gamma \\
& +0.000719 \cos 2 \Gamma+0.000077 \sin 2 \Gamma
\end{aligned}
$$

where $\Gamma$ is the day angle, calculated by using Eq. (5):

$$
\Gamma=2 \pi\left(d_{n}-1\right) / 365
$$

where $d_{n}$ is the day number of the year.

$$
\omega=\cos ^{-1}(-\tan (\varphi) \cdot \tan (\delta))
$$

$$
\begin{aligned}
& \delta=(0.006918-0.399912 \cos \Gamma+0.070257 \sin \Gamma \\
& -0.006758 \cos 2 \Gamma+0.000907 \sin 2 \Gamma+0.000907 \sin 2 \Gamma \\
& -0.002697 \cos 3 \Gamma+0.00148 \sin 3 \Gamma)(180 / \pi)
\end{aligned}
$$

After calibrating the Ångström-Prescott equation, the model was evaluated by comparison of the $H$ from daily values of $n$ observed in the conventional station and the daily values of $\mathrm{H}$ measured in automatic station during 2014 year.

The Ångström-Prescott equation performance was evaluated using the Willmott's index of agreement (d) (Eq. (8)), Mean Bias Error (MBE) (Eq. (9)), Root Mean Square Error (RMSE) (Eq. (10)), and Mean Percentage Er- 
ror (MPE) (Eq. (11)) and Pearson correlation coefficient (r) (Eq. (12)) (Willmott, 1982; Wilks, 2006; Khorasanizadeh and Mohammadi, 2013):

$$
d=1-\left[\frac{\sum_{i=1}^{N}\left(H_{i, C}-H_{i, M}\right)^{2}}{\sum_{i=1}^{N}\left(\left|H_{i, C}^{\prime}\right|+\left|H_{i, M}^{\prime}\right|\right)^{2}}\right], 0 \leq d \leq 1
$$

$$
\begin{aligned}
& M B E=N^{-1} \sum_{i=1}^{N}\left(H_{i, C}-H_{i, M}\right) \\
& R M S E=\left[N^{-1} \sum_{i=1}^{N}\left(H_{i, C}-H_{i, M}\right)^{2}\right]^{0.5} \\
& M P E=N^{-1} \sum_{i=1}^{N}\left(\frac{H_{i, C}-H_{i, M}}{H_{i, M}}\right) \times 100
\end{aligned}
$$

where $H_{i, C}$ is ith calculated $H$ value using calibrated Angström-Prescott equation, $H_{i, M}$ is $i$ th measured $H$ value on weather station, $H_{i, C}^{\prime}=H_{i, C}-H_{i, M}^{\prime}$ e $H_{i, M}^{\prime}=H_{i, M}-H_{i, M}^{\prime}$, and $H_{i, M}^{\prime}$ is average of measured values.

\section{Results and Discussion}

It is possible noted different values of coefficients to the four weather stations studied on RN relatively to proposed by Allen $e t a l$. (1998), i.e., $a$ higher than 0.25 and $b$ lower than 0.50 (Table 2). Thus, the importance of local calibration is evidenced. According Table 2, the $a$ values were predominantly higher than 0.30 , while the $b$ values were lower than 0.45 . This discrepancy with relation to recommended values (Allen et al., 1998) was similar to previ- ous studies over tropical climates region (Carvalho et al., 2011; Belucio et al., 2014). In addition, in Natal, Apodi, and Caicó, the $a$ values was lower than $b$ coefficient, while in Macau $a$ values were higher than values of $b$ during three of the four studied seasonal periods. According to Hinrichsen (1994), $a$ coefficient physically represent the fraction of diffuse radiation to $H_{0}$, while $b$ quantify the fraction of direct radiation to $H_{0}$. Thus, the results suggest larger values of direct incoming solar radiation in comparison to diffuse solar radiation over Natal, Apodi, and Caicó. In other hand, the diffuse solar radiation in Macau is higher than di-

\begin{tabular}{|c|c|c|c|c|}
\hline Weather Station & Calibration Period & Calibrated Angström-Prescott equation & $a+b$ & $\mathrm{R}^{2}$ \\
\hline \multirow[t]{5}{*}{ Natal } & DJF & $H / H_{0}=0.31+0.38(n / N)$ & 0.69 & 0.64 \\
\hline & MAM & $H / H_{0}=0.27+0.45(n / N)$ & 0.72 & 0.82 \\
\hline & JJA & $H / H_{0}=0.29+0.42(n / N)$ & 0.71 & 0.79 \\
\hline & SON & $H / H_{0}=0.31+0.38(n / N)$ & 0.69 & 0.61 \\
\hline & Annual & $H / H_{0}=0.29+0.41(n / N)$ & 0.70 & 0.75 \\
\hline \multirow[t]{5}{*}{ Macau } & DJF & $H / H_{0}=0.41+0.26(n / N)$ & 0.67 & 0.45 \\
\hline & MAM & $H / H_{0}=0.38+0.32(n / N)$ & 0.70 & 0.68 \\
\hline & JJA & $H / H_{0}=0.39+0.31(n / N)$ & 0.70 & 0.63 \\
\hline & SON & $H / H_{0}=0.32+0.36(n / N)$ & 0.68 & 0.46 \\
\hline & Annual & $H / H_{0}=0.39+0.29(n / N)$ & 0.68 & 0.58 \\
\hline \multirow[t]{5}{*}{ Apodi } & DJF & $H / H_{0}=0.32+0.41(n / N)$ & 0.73 & 0.78 \\
\hline & MAM & $H / H_{0}=0.34+0.42(n / N)$ & 0.76 & 0.71 \\
\hline & JJA & $H / H_{0}=0.35+0.40(n / N)$ & 0.75 & 0.72 \\
\hline & SON & $H / H_{0}=0.36+0.38(n / N)$ & 0.73 & 0.55 \\
\hline & Annual & $H / H_{0}=0.34+0.41(n / N)$ & 0.75 & 0.71 \\
\hline \multirow[t]{5}{*}{ Caicó } & DJF & $H / H_{0}=0.35+0.39(n / N)$ & 0.74 & 0.83 \\
\hline & MAM & $H / H_{0}=0.38+0.37(n / N)$ & 0.75 & 0.79 \\
\hline & JJA & $H / H_{0}=0.37+0.39(n / N)$ & 0.76 & 0.86 \\
\hline & SON & $H / H_{0}=0.31+0.44(n / N)$ & 0.75 & 0.79 \\
\hline & Annual & $H / H_{0}=0.36+0.38(n / N)$ & 0.74 & 0.82 \\
\hline
\end{tabular}
rect solar radiation, except from September to November period.

Table 2 - Ångström-Prescott equation with respective coefficients obtained to four weather stations by using both seasonal and annual calibrations. 


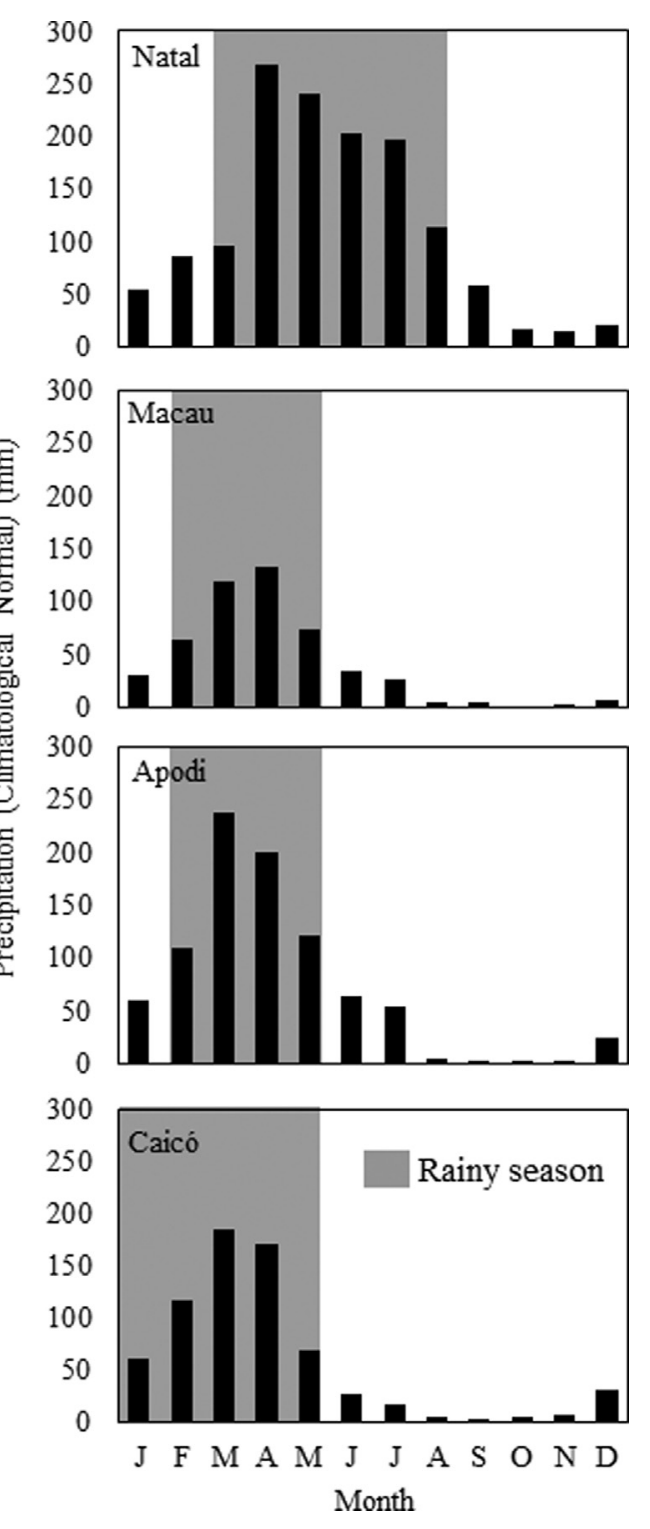

Figure 2 - Monthly climatological rainfall values of the weather stations used in this study.

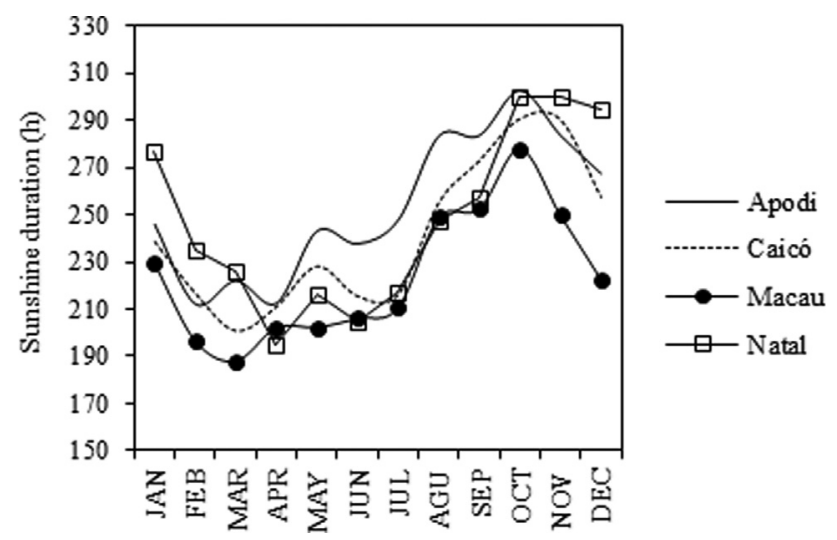

Figure 3 - Monthly climatological values of Sunshine duration in the weather stations studied.
In Natal the direct incoming solar radiation increases from March to August (rainy season), according to monthly climatological sunshine duration values showed in the Figs. 2 and 3, respectively. In Apodi, in turn, the direct incoming solar radiation increases from December to February, which is the transition period between dry and rainy season (Fig. 2), and from March to May (rainy season). During these periods in both stations the $b$ values is higher than 0.40 . This increase of direct incoming solar radiation is probably associated with the occurrence of rainfall, which causes air cleaning. The Apodi weather station, which is located on Semi-Arid region, distant about $300 \mathrm{~km}$ from ocean on the predominant wind direction, the main attenuation of solar radiation are caused by dust particles while Natal weather station, located on coast sea-salt aerosol are main solar radiation attenuating. In Caicó weather station, direct and diffuse solar radiation pattern do not change along the year, except from September to November, when a decrement of diffuse solar radiation and an increases of direct solar radiation are observed, probably due to low cloud cover on this period, which is dry season (Fig. 2).

The most effective effect of rainy season over incoming solar radiation in the Apodi weather station relatively Caicó is probably associated to climatological difference on precipitation, while Apodi the annual total climatological precipitation is about $900 \mathrm{~mm}$, Caicó region record about $650 \mathrm{~mm}$. However, the pattern of incoming solar radiation over both Apodi and Caicó weather stations is similar, according to $a+b$ sum, which is higher than 0.70 along the years (Table 2). Over Natal weather station, DJF and SON periods, corresponding dry season, $a+b$ sum is lower than 0.70 . This similar behavior during mentioned periods probably is associated to reduced rain occurrence and, consequently high sea-salt aerosol concentration on air.

The highest values of $a$ in comparison to $b$ in Macau weather station are probably associated with high sea-salt aerosol concentration on air over the Macau weather station. The high concentration is probably associated to location-climate combination. Macau weather station is located in the northern coast of $\mathrm{RN}$, and despite its location, has Semi-Arid climate, because trades wind predominantly along year are parallel to coastline and not carried humidity from ocean to continent (INMET, 1992). The northern coast of RN is the biggest sea-salt producer of Brazil because its geographic and climatic features that favors; plain lands, high temperatures, and low rain (INMET, 1992). Finally, high sea-salt aerosol concentration in the air is favored to low annual precipitation in Macau (lower than $600 \mathrm{~mm}$ annual, with about $80 \%$ concentrated on four month, Fig. 2) (INMET, 1992).

Sea-salt is an important atmospheric aerosol components (Artaxo et al., 2006; Athanasopoulou et al., 2008), produced by bursting bubbles during whitecap formation in the open-ocean (Athanasopoulou et al., 2008). A more localized mechanism of sea-salt aerosol production involves 
waves breaking in the surf zone. This mechanism may affect areas even at a distance of $25 \mathrm{~km}$ from the coastline and can dominate the coastal sea-salt aerosol levels (Athanasopoulou et al., 2008). The tropospheric aerosols directly affect the radiative balance (absorption and scattering radiation) interacting with shortwave and longwave radiation and/or indirectly (influencing the radiative properties of clouds) (Artaxo et al., 2006; A thanasopoulou et al., 2008). Other evidence of the attenuating effects from sea salt aerosols on solar radiation is the low monthly climatological values of the sunshine duration in Macau in relation to other locations, as shown in Fig. 3, especially for those where their precipitation regime is similar; Caicó and Apodi.

The performance of the Angström-Prescott equation calibrations was analyzed by comparison between the daily solar radiation estimated by using locally calibrated Ångström-Prescott equation and the measured daily solar radiation on weather stations. Broadly, the seasonal calibrations have the best performances (see statistical analysis, Table 3). Although both seasonal and annual calibrations had similar performance, in all studied stations; the RMSE is lower than $2.0 \mathrm{MJ} \mathrm{m}^{-2}$ day $^{-1}$, and very strong correlations (greater than 0.90 ), with statistically significant at $\mathrm{p}<0.05$ level. Willmott's index of agreement were greater than 0.90, MBE less than $1.2 \mathrm{MJ} \mathrm{m}^{-2} \mathrm{day}^{-1}$, and MPE lower than $3.0 \%$ except in Macau weather station where MPE was higher than $6 \%$.

The good performance achieved by ÅngströmPrescott equation in this study has been recurring in other studies in Brazil and around the world (Iziomon and Mayer, 2002, Carvalho et al., 2011, Srivastava and Pandey, 2013, Rahimi et al., 2012, Khorasanizadeh and Mohammadi, 2013). On the other hand, the performance here found has been better than another regions such as in China (Liu et al., 2012), Karaj, Shiraz, Tabriz, and Tehran, Iran (Khorasanizadeh and Mohammadi, 2013), Macapá (Belúcio et al., 2014), and Ponta Grossa (Beruski et al., 2015).

The strong correlation submitted in this study by both seasonal and annual calibrations are shown in Fig. 4, where are given the scatter plot between the estimated daily solar radiation by using seasonal calibration and the measured
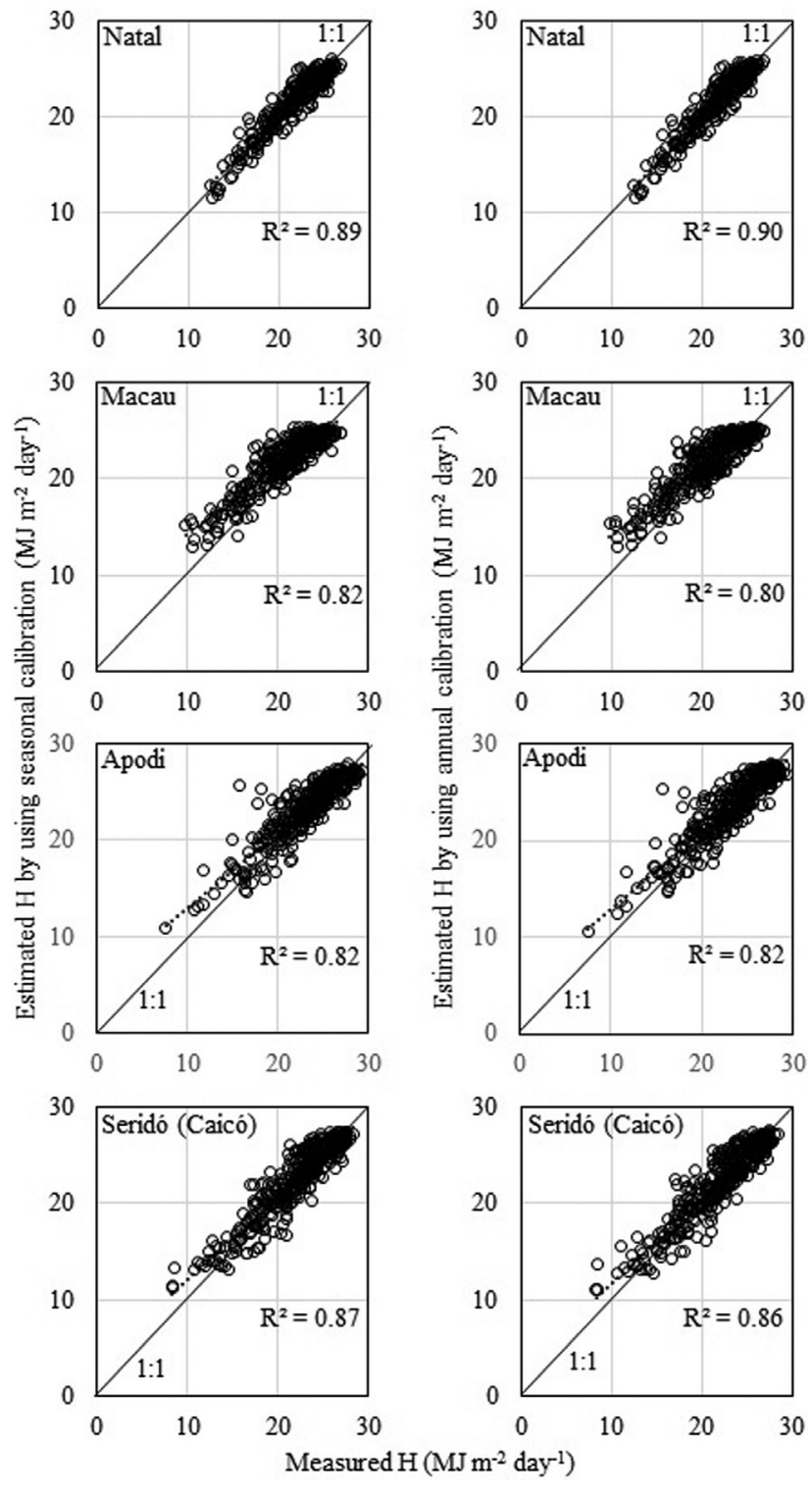

Figure 4 - Scatter plot between estimated daily solar radiation by using seasonal calibration and measured daily solar radiation (left panel) and between estimated daily solar radiation by using annual calibration and measured daily solar radiation (right panel).

Table 3 - Performance statistical analysis of the Ångström-Prescott equation with different calibrations.

\begin{tabular}{|c|c|c|c|c|c|c|}
\hline Station & Calibration & $\operatorname{RMSE}\left(\mathrm{MJ} \mathrm{m}{ }^{-2} \mathrm{dia}^{-1}\right)$ & $r(-)$ & $d(-)$ & $\operatorname{MBE}\left(\mathrm{MJ} \mathrm{m}^{-2} \mathrm{dia}^{-1}\right)$ & MPE (\%) \\
\hline \multirow[t]{2}{*}{ Natal } & Seasonal & 1.01 & 0.95 & 0.97 & -0.080 & -0.22 \\
\hline & Annual & 1.02 & 0.95 & 0.97 & -0.093 & -0.37 \\
\hline \multirow[t]{2}{*}{ Macau } & Seasonal & 1.92 & 0.91 & 0.91 & 1.107 & 6.54 \\
\hline & Annual & 1.94 & 0.89 & 0.91 & 1.040 & 6.21 \\
\hline \multirow[t]{2}{*}{ Apodi } & Seasonal & 1.64 & 0.90 & 0.94 & 0.134 & 1.37 \\
\hline & Annual & 1.64 & 0.90 & 0.95 & 0.300 & 2.01 \\
\hline \multirow[t]{2}{*}{ Caicó } & Seasonal & 1.51 & 0.93 & 0.96 & 0.415 & 2.64 \\
\hline & Annual & 1.49 & 0.96 & 0.96 & 0.420 & 1.75 \\
\hline
\end{tabular}


daily solar radiation (left panel) and between the estimated daily solar radiation by using annual calibration and the measured daily solar radiation (right panel) to 2014 to four meteorological stations on Rio Grande do Norte State. It can be seen that for both seasonal and annual calibrations the estimates daily have a strong correlation between the values of estimated and measured, what means that the estimated data represent well the data measured. The $\mathrm{R}^{2}$ values found in this study is higher than 0.80 significance level at 0.05 , are better than the found by Srivastava and Pandey (2013).

According to Table 3 and Fig. 4, it appears that the performances of both seasonal and annual calibrations were virtually identical. These results ensure reliability for both seasonal and annual calibrations considering the confidence level of statistical analysis. Probably this similarity is associated to the proximity from the weather stations to equator. This implies that the variation between the maximum and minimum sunshine duration and consequently maximum and minimum daily solar irradiance (solstices of winter and summer austral) is very small. In this case, the use of both seasonal and annual calibrations to estimate daily global solar radiation is optional.

\section{Conclusions}

Ångström-Prescott equation has been calibrated to four weather stations within Rio Grande do Norte, seasonally, i.e. specifically for each seasons, and single calibration for the entire period (annual). The performance of calibrated Ångström-Prescott equation was evaluated. Both seasonal and annual calibrations has satisfactory performance since the comparison between their estimates of daily global solar radiation with the measured daily global solar radiation values showed strong correlations, high concordance index and high determination coefficient. The seasonal calibration showed performance slightly higher than the annual calibrations because presented greater correlation coefficient beyond RMSE, MBE, and MPE lightly lower compared to the results of the annual calibration. The performances of both seasonal and annual calibrations are similar and their use to estimate daily global solar radiation is optional. The weakest performance of the ÅngströmPrescott equation was found in Macau weather station. The performance of Ångström-Prescott equation in this weather station was probably affected by the high concentration of sea-salt aerosols.

\section{Acknowledgments}

The author thanks the National Institute of Meteorology of Brazil (INMET) for providing the daily data of sunshine and global solar radiation.

\section{References}

ALLEN, R.G.; PEREIRA, L.S.; RAES, D.; SMITH, M. Crop evapotranspiration-guidelines for computing crop water requirements. Rome: United Nation FAO, Irrigation and drainage paper, paper $\mathrm{n}^{\circ} 56,1998$.

ALMOROX, J.; BENITO, M.; HONTORIA, C. Estimation of monthly Angström-Prescott equation coefficients from measured daily in Toledo, Spain. Renewable Energy, v. 30, p. 931-936, 2005

ÅNGSTRöM, A. Solar and atmospheric radiation. Quarterly Journal of the Royal Meteorological Society, v. 50, p. 121-126, 1924

ARTAXO, P.; OLIVEIRA, P.H.; LARA, L.L.; PAULIQUEVIS, T.M.; RIZZO, L.V.; et al. Efeitos Climáticos de Partículas de Aerossóis Biogênicos e Emitidos em Queimadas da Amazônia. Revista Brasileira de Meteorologia, v. 21, p. 168-122, 2006.

ATHANASOPOULOU, E.; TOMBROU, M.; PANDIS, S.N.; RUSSEL, A.G. The role of sea-salt emissions and heterogeneous chemistry in the air quality of polluted coastal areas. Atmospheric Chemistry and Physics, v. 8, p. 5755-5769, 2008.

BELÚCIO, L.P.; SILVA, A.P.N.; SOUZA, L.R.; MOURA, G.B.A. Radiação Solar Global Estimada a partir da Insolação para Macapá (AP). Revista Brasileira de Meteorologia, v. 29, p. 494-504, 2014.

BERUSKI, G.C.; PEREIRA, A.B.; SENTELHAS, P.C. Desempenho de Diferentes Modelos de Estimativa da Radiação Solar Global em Ponta Grossa, PR. Revista Brasileira de Meteorologia, v. 30, p. 205-213, 2015.

CARVALHO, D.F.; SILVA, D.G.; SOUZA, A.P.; GOMES, D.P.; ROCHA, H.S. Coeficientes da equação de AngströmPrescott e sua influência na evapotranspiração de referência em Seropédica, RJ. Revista Brasileira de Engenharia Agrícola e Ambiental, v. 15, p. 838-844, 2011.

DORNELAS, K.D.S.; SILVA, C.L.; OLIVEIRA, C.A.S. Coeficientes médios da equação de Angström-Prescott, radiação solar e evapotranspiração de referência em Brasília. Pesquisa Agropecuária Brasileira, v. 41, n. 8, p. 1213-1219, 2006.

HINRICHSEN, K. The Angstrom formula with coefficients having a physical meaning. Solar Energy, v. 52, p. 491-495, 1994.

INMET - Instituto Nacional de Meteorologia, Normais Climatológicas do Brasil 1961-1990. Brasília: INMET, 1992, 84p. Available in: http://www.inmet.gov.br/portal/index.php?r= clima/normaisClimtologicas.

IQBAL, M. An Introduction to Solar Radiation. San Diego: Academic Press, 1983. 390 p.

IZIOMON, M.G.; MAYER, H. Assessment of some global solar radiation parameterizations. Journal of Atmospheric and Solar-Terrestrial Physics, v. 64, p. 1631-1643, 2002.

KHORASANIZADEH, H.; MOHAMMADI, K. Introducing the best model for predicting the monthly mean global solar radiation over six major cities of Iran. Energy, v. 51, p. 257$266,2013$.

LIU, X.; MEI, X.; LI, Y.; ZHANG, Y.; WANG, Q.; JENSEN, J.R.; PORTER, J.R. Calibration of the Angström-Prescott coefficients $(a, b)$ under different time scales and their impacts in estimating global solar radiation in the Yellow River 
basin. Agricultural and Forest Meteorology, v. 149, p. 696-710, 2009.

LIU, X.; XU, Y.; ZHONG, X.; ZHANG, W.; PORTER, J.R.; LIU, W. Assessing models for parameters of the AngströmPrescott formula in China. Applied Energy, v. 96, p. 327338, 2012.

MEESANG, W.; BUALERT, S.; WONGLAKORN, P. Sea Salt Aerosols: Shortwave Radiative Forcing. International Journal of Environmental Science and Development, v. 4, n. 2, p. 104-106, 2013.

MORADI, I. Quality control of global radiation using sunshine duration hours. Energy, v. 34, p. 1-6, 2009.

OKUNDAMIYA, M.S.; EMAGBETERE, J.O.; OGUJOR, E.A. Evaluation of various global solar radiation models for Nigeria. International Journal of Green Energy, v. 13, n. 5, p. 505-512, 2016.

PRESCOTT, J.A. Evaporation from a water surface in relation to solar radiation. Transactions of the Royal Society of South Australia, v. 64, p. 114-480, 1940.

RAHIMI, I.; BAKTIARI, B.; QADERI, K.; AGHABABAIE, M. Calibration of Angstrom equation for estimating Solar Radiation using Meta-Heuristic Harmony Search Algorithm (Case study: Mashhad-East of Iran). Energy Procedia, v. 18 , p. 644-651, 2012.

SANTOS, C.M.; SOUZA, J.L.; FERREIRA JÚNIOR, R.A.; TIBA, C.; MELO, R.O. et al. On modeling global solar irradia- tion using air temperature for Alagoas State, Northeastern Brazil. Energy, v. 71, p. 388-398, 2014.

SEN, Z.; ÖZTOPAL, A.; SAHIN, A.D. Application of generic algorithm for determination of Angström equation coefficients. Energy Conservation \& Management, v. 42, p. 217-231, 2001.

SPENCER, J.W. Fourier series representation of the position of the Sun. Search, v. 2, p. 162- 172, 1971.

SRIVASTAVA, R.C.; PANDEY, H. Estimating ÅngströmPrescott Coefficients for India and Developing a Correlation between Sunshine Hours and Global Solar Radiation for India. ISRN Renewable Energy, Article ID 403742, 2013.

TAKEMURA, T.; NAKAGIMA, T.; DUBOVIK, O.; HOLBEN, B.N.; KINNE, S. Single-scattering albedo and radiative forcing of various aerosol species with a global threedimensional model. Journal of Climate, v. 15, p. 333-352, 2002.

THORNTHWAITE, C.W. An Approach toward a Rational Classification of Climate. Geographical Review, v. 38, p. 5594, 1948.

WILKS, D.S. Statistical Methods in the Atmospheric Science. $2^{\text {nd. }}$ Ed. San Diego: Academic Press, 2006. 627 p.

WILLMOTT, C.J. Some Comments on the Evaluation of Model Performance. Bulletin of the American Meteorological Society, v. 63, p. 1309-1313, 1982.

This is an Open Access article distributed under the terms of the Creative Commons Attribution Non-Commercial License which permits unrestricted non-commercial use, distribution, and reproduction in any medium provided the original work is properly cited. 